Scientia Militaria vol 44, no 1, 2016, pp 5-21. doi:10.5787/44-1-1159

\title{
South Africa Mobilises: The First Five Months of the War
}

\author{
Dr Anne Samson •
}

\begin{abstract}
When war broke out in August 1914, the Union of South Africa found itself unprepared for what lay ahead. When the Imperial garrison left the Union during September 1914, supplies, equipment and a working knowledge of British military procedures reduced considerably. South Africa was, in effect, left starting from scratch. Yet, within five months and despite having to quell a rebellion, the Union was able to field an expeditionary force to invade German South West Africa and within a year agree to send forces to Europe and East Africa. This article explores how the Union Defence Force came of age in 1914.
\end{abstract}

Keywords: South Africa, mobilisation, rebellion, Union Defence Force, World War 1

\section{Introduction}

In August 1914, South Africa, along with many other countries, found itself at war. It was unprepared for this eventuality - more so than most other countries. Yet, within six weeks of war being declared, the Union sent a force into neighbouring German South West Africa. This was a remarkable achievement considering the Union's starting point, and that the government had to deal with a rebellion, which began with the invasion.

The literature on South Africa's involvement in World War 1 is increasing. Much of it focused on the war in Europe $^{1}$ and, more recently, on East Africa ${ }^{2}$ with South West Africa ${ }^{3}$ starting to follow. However, the home front has been largely ignored with most literature focusing on the rebellion, which ran from September to December 1914. ${ }^{4}$ This article aims to explore South Africa's preparedness for war and to shed some insight into the speed with and extent to which the government had to adapt in order to participate successfully in it. The article starts by setting out the military position of the Union in July 1914, followed by a broad overview of the political aspects concerning the war. Some actions the Union took to enable the invasion of German South West Africa (GSWA) in mid- to late September 1914 and how the concurrent rebellion affected the Union's preparations are discussed. The article concludes with a brief assessment of what had been achieved by the end of December 1914 when the Union in effect re-launched its invasion of the German colony following the rebellion.

\section{The military situation at the outbreak of war}

In July 1914, the Union Defence Force (UDF) was experiencing the growing pains of a typical two-

\footnotetext{
Dr Anne Samson is an independent historian who has published two books on the First World War in Africa and numerous articles on related themes including the role of the historical novel in writing history. She has also given various talks on aspects of the war in Africa. Anne is the co-ordinator of the Great War in Africa Association http://gweaa.com and is on the Scientific Council of the International Network for the Study of the Great War in Africa hosted by Faculty of Social Sciences and Humanities, Universidade Nova de Lisboa.
} 
year-old. It was trying to forge its identity and determine its place in the Union of South Africa, itself only four years young. The UDF came into being by an Act of Parliament in 1912, bringing together the various military bodies which had operated in each of the colonies from before Union. Between Union in 1910 and the formation of the UDF, the Defence Department consisted of the Minister for Defence, Jan Smuts, and his civilian under-secretary, HRM Bourne. ${ }^{5}$ In 1912, a core of 51 officers filled positions in the UDF headquarters in Pretoria and the 15 military regions across the country. The UDF consisted of the Permanent Force under Col. HT Lukin which was made up of five South African Mounted Rifle Regiments, ${ }^{6}$ the Active Citizen's Force under Col. CF Beyers, consisting of 25 $155 \mathrm{men}^{7}$ and the Cadets (13-17-year-olds) under the leadership of Col. PS Beves. In addition to the UDF, the South African Police which, on 1 April 1913, numbered 5882 men, was responsible for policing the towns. Rural policing fell to the South African Mounted Riflemen (SAMR) of the Permanent Force. ${ }^{8}$ Alongside these Union forces was the Imperial garrison under the command of the British War Office and the Officer Commanding South Africa. ${ }^{9}$ Although the UDF had been called into action to deal with strikes in 1913 and early $1914,{ }^{10}$ the various groups still functioned separately, and these divisions led to "disjointed development of war planning and created distrust, even fission in the new structures" ${ }^{11}$ The outbreak of war was to provide a catalyst to enforce change.

Following the 1912 approval of the Defence Force, Bourne's role was developed into a secretariat, which remained dominated by civilians. A General Staff was introduced to oversee the military organisation and an administration was formed to co-ordinate logistics and supplies. ${ }^{12}$ South Africa had a system in place to support the expansion of the armed forces but this was still in its infancy, having first been introduced in 1913. It included the "annual domestic service" or "peace training camps" where men aged 17 to 60 were called up in August to undergo military training over a period of four years. ${ }^{13}$

\section{The political situation at the outbreak of war}

The formation of the Union of South Africa on 31 May 1910 brought together two British-dominated territories, the Cape and Natal, and two Boer-dominated territories, the Orange River and Transvaal. The Act of Union made provision for an "Executive Government" which was "vested in the King", and "administered by His Majesty in person or by a governor-general as His representative." The Union was to be administered by an executive committee which would act as an advisory body. "The command in chief of the naval and military forces within the Union" was "vested in the King or Governor-General as His representative". ${ }^{14}$ Legislative power was "vested in the Parliament of the Union", consisting "of the King, a Senate, and a House of Assembly", which met in Cape Town; Pretoria being the "seat of Government". This meant decisions were made in Cape Town whilst administration was based in Pretoria - at least one whole day's train journey away. The sessions of Parliament would be determined by the Governor-General and he could also "from time to time, by proclamation or otherwise, prorogue Parliament, and [...] in like manner dissolve the Senate and the House of Assembly". English and Dutch were the official languages. ${ }^{15}$

Representing the white people in Parliament were various political parties. The governing South African Party led by Louis Botha and Jan Smuts represented a mix of Boer/Afrikaner and English speakers and was the most national of the parties. The SAP together with the Englishspeaking Unionist Party, which in the main represented the mining magnates and those with strong ties to Britain, were pro-Empire. The anti-Empire sector was represented by the National Party, which had come into being in February 1914 after Louis Botha had left JBM Hertzog out of his cabinet. Bridging the pro- and anti-Empire positions was the Labour Party, which aligned itself with the Nationalists before the outbreak of war as both parties were anti-British capitalist; the latter 
represented by the Unionist Party. Leading the parties in the House of Assembly was the Prime Minister, Louis Botha of the South Africa Party. ${ }^{16}$ Black, coloured and Indian peoples had little political involvement although some coloureds, who met the requirements, were allowed the vote in the Cape.

\section{The outbreak of war}

As war loomed, South Africa was without its governor-general ${ }^{17}$ and prime minister. July was the holiday season, which allowed government officials to return to England to liaise with Colonial and War Offices and other departmental officials. At the beginning of July 1914, Viscount Gladstone, Governor-General of South Africa from 1910, returned to England having resigned his post. His replacement, Sydney Buxton, was due to leave for South Africa at the beginning of August and on his arrival in the country in September, Parliament would meet. In the interim, the post was filled by Lord Chief Justice Sir John Henry de Villiers and when he died three days before Buxton's arrival, by Sir James Rose Innes, Attorney General. ${ }^{18}$ On 1 August 1914, Prime Minister Louis Botha, was ending a tour of Southern Rhodesia where he had been campaigning for the British South African Company chartered territory to join the Union. Botha, having been warned of the pending outbreak of war by the South African agent to London, David Graaff, returned overland rather than sail from Beira in Portuguese East Africa on a German ship as initially planned. ${ }^{19}$ Had Botha sailed, it is likely he would have been the only head of state to be taken prisoner during the war.

On 4 August 1914, the day Britain declared war on Germany, the Union government, with Botha safely in the chair, reassured London of its support. In response, Britain, on 6 August, asked South Africa to "seize such part of German South West Africa as will give them the command of Luderitzbucht, Swakopmund and the wireless stations there or in the interior". ${ }^{20}$ In Pretoria, Botha called his cabinet together on 7 August, to discuss the situation, extending the remit from one of destroying the wireless stations to invading and capturing the entire German colony. The cabinet was divided but Botha won his point by warning his colleagues that there was nothing to prevent Britain from asking Australia or India to undertake the task. Despite their fear of dividing white South Africa and re-opening wounds, which had slowly started to heal after the Anglo-Boer War of 1899-1902, FS Malan and his fellow dissenters agreed with Botha. There was no objection to the Union undertaking its own defence and allowing the Imperial garrison to return to Britain, ${ }^{21}$ a move which Britain welcomed, and all but one and a quarter battalions left for Europe on 27 August taking all their equipment with them. ${ }^{22}$ The remaining Imperial troops relocated to the Castle in Cape Town ${ }^{23}$ where, under the command of Maj. Gen. Charles Thompson, they provided South Africa with much-needed advice and support.

The cabinet having agreed to take on the defence of the Union and to invade GSWA triggered the Ministry of Defence into action. Although steps could be taken to prepare for the invasion, permission to invade could only be given when Parliament sat a month later, in September, and there was no guarantee that members would approve the move. This meant that some preparations had to be kept out of the public domain as they would contravene the spirit of the Defence Act. Others, however, could be actioned under the guise of protecting the Union against potential attack. ${ }^{24}$

\section{Planning the campaign and protecting the Union}

Despite there being a fair bit to do, the Union government was not under the same pressure as Britain to get forces to the front, as the Union was surrounded by friendly powers on all sides, except for 
GSWA. With the Kalahari Desert being the main feature of the countryside, it was unlikely an attack would come from there, but one had to be prepared. The rush, ostensibly to fulfil the British (Admiralty) request to put the wireless stations out of action, was really to ensure the German colony would fall to the Union before the war was over. ${ }^{25}$ The Union government knew what it was up against as the challenges of the territory had been set out in the Military report on GSWA 1913 and a number of South Africans had 'insider' information. These included Capt. Johan Leipoldt, a Namakwalander, and Thomas Cullinan, who had prospected in the Kuruman area. ${ }^{26}$ The speed with which government looked to invade GSWA meant that a combination of systems and processes was used, resulting in apparent confusion and a lack of organisation. ${ }^{27}$

The Royal Naval Volunteer Reserve in Durban was mobilised on 5 August, whilst the Natal units of the Defence Force, including the Durban Light Infantry and Natal Carbineers, mobilised on 8 August to protect against coastal invasion and to relieve the Imperial garrison, which left Durban on 12 August 1914 for Cape Town. ${ }^{28}$ Additional forces were put on alert following the apparent sighting of the SS Königsberg 18 miles off the Durban coast, and an 'examination service' started to assess all ships which entered the port. ${ }^{29}$

The naval commander-in-chief, Admiral Herbert King Hall, was in an unenviable position. He was, until October 1914, responsible for the whole coastline around southern Africa stretching from St Helena on the west coast to Mombasa on the east. He had three out-dated cruisers with which to patrol the waters - HMS Pegasus, Astrea and Hyacinth - until HMS Pegasus was sunk in Zanzibar harbour by SS Königsberg on 20 September $1914 .{ }^{30}$ In addition to patrolling the waters, until Königsberg was spotted on 30 October in the Rufiji Delta, King Hall was responsible for protecting the ports against invasion and preventing German commercial shipping from reaching its destination. Already by 20 August, three German ships had been apprehended and passed to the Prize Courts. The award of a prize ship would significantly improve transport opportunities for the country involved. Yet, King Hall could only start proceedings to claim prize ships after he had received the Prize Court Rules on 18 September. ${ }^{31}$ Claims needed to be prepared and cases made for why the Union should be awarded a ship rather than, for example, Australia, which often had a claim over the same ship as it was scheduled to make a delivery there but was caught in South African waters or vice versa. ${ }^{32}$

The need for shipping to support the campaign in GSWA was great, and boats of all sizes were sourced from wherever possible. The Durban Light Infantry historian recorded surprise when, on arrival at Walfisch Bay, the regiment came across the Durban tug Sir John, which was doing its bit to support the war effort. ${ }^{33}$ Apart from sourcing vessels for various functions, King Hall had to arrange for the Imperial garrison to be transported and escorted back to Europe as well as supply the transport and escort for the Union's expeditionary forces invading GSWA. He had at his disposal the Union Castle line, but that only solved part of his problem as escort ships were scarce. The date for transporting the South African expeditionary force therefore moved from 5 to 12 September when Astrea was promised as escort. However, this deadline, too, moved to 14 September due to poor weather conditions, and then to 26 September. ${ }^{34}$ By then, the rebellion had started.

\section{The rebellion}

The rebellion was to prove a blessing in disguise for the Union government. Planning for the invasion of GSWA had started in Pretoria during August. Those present included Smuts, Beyers, Lukin, McKenzie, Beves, Col. PCB Skinner on loan from the British Army and the General Manager of Railways, Sir William Hoy. On 17 August, the Governor-General was informed of the arrangements to place troops on the Union-German border. ${ }^{35}$ Two days later, 19 August, German troops were 
reported trespassing on Union territory at Nakob. ${ }^{36}$ This was announced in the press on 21 August. The ground was set, fortuitously or contrived, to justify the Union invasion of its neighbour. ${ }^{37}$ On 30 August, 1500 men and 1300 animals left for Port Nolloth, Northern Cape, in preparation for the invasion of GSWA. ${ }^{38}$ By the time Parliament met and agreed to the invasion by 92 votes to 12 , preparations appeared complete as orders to entrain and attack GSWA were given on Tuesday 15 September 1914 - the day Generals Beyers and Kemp resigned their posts starting phase one of the rebellion. The government accepted the resignations on 19 September when letters from both Beyers and government were published in the press. ${ }^{39}$ An exacerbating factor, often treated as an inconsequential sideshow, was the hunt for the Foster Gang, which resulted in the accidental death of Gen. De la Rey on 15 September. Gen. Beyers who was in the car with De la Rey claimed that the shooting had been a deliberate act ordered by Botha and Smuts, thereby increasing the tensions between the pro- and anti-British factions. ${ }^{40}$

Although the Defence Department had numerous resignations to process, including rifle collection, ${ }^{41}$ contingency plans were put in place due to the questionable loyalty of senior military officers such as Beyers, SG (Manie) Maritz and Jopie Fourie. Already in early September, McKenzie's orders had been changed without Beyers being told. ${ }^{42}$ Maritz and a force of 1000 with no artillery were sent towards Kakamas and Upington, and Lukin was sent to Steinkopf on 20 September "to establish a base for operations [...] while the Union Department of Defence was busily engaged in organising a field force for the conquest of [GSWA]". ${ }^{43}$ Steps were also taken to invest Lüderitzbucht and Swakopmund in order to put the wireless stations out of action. The need to occupy these bases, Lüderitzbucht in particular, was made more urgent by unrest which was flaring in Walfisch Bay and the navy's concern that it could not protect shipping or the ports due to commitments on the east African coast. On 18 September, Lüderitzbucht was occupied without a shot fired, and eight days later, the battle of Grassplatz took place, 19 kilometres east of the port. Four men of the Imperial Light Horse were killed as were four Germans. ${ }^{44}$ The same day, 26 September, the South Africans suffered a major setback at Sandfontein at which 16 South Africans and 14 Germans lost their lives. ${ }^{45}$ Two days later, the Union government agreed to withdraw the magistrate and residents from Walfisch Walvis Bay until the town's security could be ensured. ${ }^{46}$ No doubt, the decision was influenced by the losses at Sandfontein and Grassplatz despite Beves's report only being written on 3 October. ${ }^{47}$

Meanwhile, Prime Minister Louis Botha took to the field as commander-in-chief. He led the loyal forces against the rebels and insisted that the only way the invasion of the German colony would succeed was if he personally commanded the expedition. This led to a reworking of the invasion strategy, which was presented to Buxton on 8 October. Botha and Smuts had never had to co-ordinate with another military body, especially naval, in any of their previous campaigns. Therefore, the month-old Governor-General took the opportunity to bring the Union planners together with the British naval commander for the Cape squadron. Action was dependent on the availability of the Navy and would utilise the various guns the Imperial authorities had placed at the disposal of the Union. ${ }^{48}$ On 9 October 1914, the naval commander-in-chief telegrammed to Buxton that he was -

coming to Pretoria by special train on Sunday at 11 am [...] I should be glad to proceed immediately to discussion of matters mentioned in your secret telegram of 7 October 1914, so that if possible I can leave again on Sunday evening. I am bringing Captain [RCK] Lambert with me and can leave him behind at Pretoria if necessary to arrange any details. ${ }^{49}$

Whilst these plans were being finalised, the Union government, with Botha in the field and kept up to date by daily telephone calls to Smuts, ${ }^{50}$ continued to work at bringing the rebellion to an end, whilst the Governor-General continued to do what he could to assist the Union government in obtaining additional equipment and forces. ${ }^{51}$ Once again, however, plans had to change at the end of 
November when information received from the Admiralty caused the Walfisch Bay expedition to be postponed for a fortnight. By then, it was hoped that the marauding German squadron would be accounted for. In the meantime, it was anticipated that an early arrangement could be arrived at to convey the bulk of 2000 men and some guns to reinforce McKenzie. ${ }^{52}$

\section{To recruit or not}

Determining the size of the force needed to protect the Union and to invade GSWA required careful thought and constant adjustment to meet the changing circumstances. Initially, on 4 August 1914, it was thought that only the Permanent Force would be used, which was in keeping with the Defence Act, as the use of volunteers especially outside of the Union would require permission from Parliament. Gordon Wills, a young traveller, wrote to his mother from a "train to Pretoria" on 14 August 1914, "Everything [...] is quiet up here and there is a large notice that no volunteers are wanted though I expect that to be ended shortly". ${ }^{53}$ Wills was right. Smuts was in communication with senior military officers about using volunteers and on 8 August, permission had been obtained from London to mobilise the Union and Imperial forces. ${ }^{54} \mathrm{~A}$ few days later, Smuts telegrammed to Col. Charles Crewe, member of the Union Parliament and owner of an East London newspaper, regarding a statement issued to the press that afternoon, 11 August:

to the effect that Government propose to organise and equip an adequate force to provide for contingencies and that besides Defence Force stop My idea is to have outside Defence Force one volunteer regiment for Natal one for East London Port Elizabeth and surrounding districts and two in the interior $[\ldots]$ Do you agree generally stop $[\ldots]^{55}$

In response, Crewe recommended that officers be drawn from the SAMR or police and that they choose their own men. ${ }^{56}$ The same day, Smuts explained to McKenzie -

$[\ldots]$ we are to a large extent dependent on the lead given us by the Imperial Government and are in communication with them. In the meantime, we think it our duty to organise and mobilise a fighting force in case of eventualities. From a notice issued yesterday [...] you will see that we intend calling not only our Defence Forces but also to a limited extent on outside volunteers. ${ }^{57}$

Ten days later, the situation had changed following the German incursion at Nakob. McKenzie would now be expected to "attempt the occupation of Luderitzbucht and Swakopmund. No volunteer regiment has been organised." 58 A month later, with the rebellion underway, Smuts informed Denys Reitz that only volunteers would be used and that no commandeering would take place. ${ }^{59}$ The concern about commandeering had been exacerbated by the annual domestic service call-up, which had taken place at the same time as the news of war that had broken out. Using volunteers would avoid having to deal with anti-British feeling in the Active Citizen's Force, which was becoming more apparent as plans for the invasion of GSWA progressed. In addition, the use of volunteers would go some way to maintaining a balance between the demands of the war and rebellion with the increased white fears of black uprisings. Withdrawing the rural police, the SAMR or Permanent Force exacerbated this fear as noted by concerned citizens in Alexandria, East London District. ${ }^{60}$ Allowing men to stay and protect their property would reduce hostility towards government.

Various routes were, therefore, used to obtain troops. The traditional commando system was put into action where many of the commando leaders who were serving officers in the UDF went out to recruit their followers. As a result, the forces serving in GSWA were recorded as Botha's Horse, De la Rey's Scouts and so on. Some citizens felt their duty lay in offering their services, for example, Crewe, who had written to Botha on 6 August 1914, and Thomas Cullinan of Premier Mines. ${ }^{61}$ Others wrote to Smuts for permission to raise a force, ${ }^{62}$ whilst some, such as George Farrar, were specifically 
asked to help. ${ }^{63}$ Finally, individuals were seconded from other departments or forces and asked to lead a regiment, for example, Lt Col. MM Hartigan of the police.

Hartigan's account of his appointment shows how quickly things could move if needed. He was ordered to Pretoria by Smuts after the defeat of the South Africans at Sandfontein ${ }^{64}$ on 26 September 1914, and asked how long it would take to raise a mounted regiment: a month if he could use a squadron of South African Police and Southern Rifles from the Transkei where he was based. Smuts approved -

On leaving Defence HQ, I went to see the Commissioner of Police, Smuts's Secretary had already telephoned him and the Minister for Justice, and my immediate secondment for Active Service was approved. The authority for formation of a regiment of four squadrons to be known as Hartigan's Horse appeared in Union Defence Force orders that night. ${ }^{65}$

In addition to the communications, which the above arrangements entailed, the Union government also had to deal with enthusiastic individuals who were recruiting contingents for service in Europe. Within a week of the incursion at Nakob, Capt. E Beardmore of the Legion of Frontiersmen Cape Colony and Rhodesia Commands offered 250 men at 48 hours' notice to government if needed. This was declined the next day. Yet, a week later, on 1 September 1914, Beardmore wrote to John Parker, the mayor of Cape Town, that recruiting in the City Hall vestibule that day had been successful. They enlisted 18 men in addition to their existing 250. He did not "consider it advisable to continue tomorrow for fear of enlisting those of an undesirable class and moreover to protect the claims for service of the present command". ${ }^{66}$ Two weeks later, on 14 September, James Wolfe Murray, Army Headquarters Cape Castle, notified Parker that the War Office had declined any further recruits from South Africa except for those needed to complete the unit strengths of the British forces already in the Union. Two days later, however, Sir Percy Fitzpatrick and Col. Byron in conjunction with Sir Aubrey Woolls Sampson had placed an article in the press for men to volunteer. Within days, on 19 September, Buxton urgently telegraphed London noting, "Ministers would deprecate recruitment at present of any such contingent" as they were about to issue a call for 7000 veterans to volunteer for service in GSWA. Government sought permission to add to their call a message from the Imperial government that "it would not encourage recruitment of oversea contingent until satisfied [that Union requirements were fully met]". ${ }^{67}$ This contrasts with a letter Smuts sent to the of Cape Town a week earlier notifying him that the Defence Force was not in a position to enlist further recruits. ${ }^{68}$ The Union government was clearly reacting to changing circumstances rather than following a defined policy.

Some, however, did appear to work in conjunction with the authorities as noted by Percival $\mathrm{F}$ Smith $^{69}$ of the People's Legion: ${ }^{70}$

Activities: The Legion is at present confining its activities to dealing with men who either cannot or will not enlist in the Botha Army or the Defence Force. All men who are eligible for those forces are being urged by the Legion to go forward to the City Hall. It is found that there are a number of men who have served in the Imperial Army and who desire to rejoin their old regiments. The Legion is dealing with applications from such men, and is trying to send such men to England. It seems but natural that these men should be given a chance of rejoining the colours.

It must be remembered that the Legion will not send away men who are wanted by the Union Government and whose services can be obtained for the Government. It is only sending away men whose services are not forthcoming for local purposes who have special qualifications for serving in the British army, and whom Earl Kitchener has said he will be very glad to receive. Seventy six of such men have already been sent. It is estimated that to send 25 men each week costs $£ 350$. The Legion is doing its best to help locally. It is also trying to keep the Imperial point of view in mind $\cdots$ 
Over the next ten days, updates appeared on the progress of recruitment for Overseas Contingent No 4. On 8 October, it was noted that the contingent of 50 men would be sailing at the end of the following week. But, when the Commandant of Rhodesia was unable to entrain men to reach Cape Town in time for the ship to leave, the People's Legion recruited additional men to fill these spaces. They sailed on 17 October on RMS Norman after parading for inspection by Maj. Gen. Thompson who had replaced Wolfe Murray as senior commander of the Imperial garrison.

Over time and alongside the traditional recruitment routes, the 15 military centres across the Union became centres for recruitment, eventually becoming more aligned under the Director for Recruiting, CP Crewe, in Pretoria. ${ }^{71}$ On 25 September 1914, magistrates and police officers across the Union were asked to assist the Director "as much as possible". ${ }^{72}$ Recruitment drives were organised where politicians and senior military officials were sent to rally men to enlist. This may well account for the work of the People's Legion described above. However, not all recruitment drives were well thought out as noted by Col. Coen Brits, a Boer, being sent to "English" East London. After Brits had left, local senior officers offered to raise a "complete mounted regiment" for service in East Africa if they could have Hartigan as their commander. Hartigan's appointment to $9^{\text {th }}$ South African Horse was realised on 26 September, by which time the number of civil servants and police enlisting had started to affect the running of the country, and Botha banned staff resigning and secondment to the armed forces for the remainder of the war. ${ }^{73}$

Recruitment stations were developed, with all they entailed. Attestation forms needed processing so men could be paid. This was to be a complex process as there were different rates depending on where men served and in which capacity. ${ }^{74}$ Separation allowances and having payments sent to different family members added to the processes. Recruiting administrators were to ensure that applicants met the requirements in terms of age and ethnicity - no person of colour or of enemy background was to be enlisted into the armed regiments of the Union Defence Force. Doctors had to be recruited to complete the medical tests all men had to undergo before being allowed to progress to training. Each recruit underwent two medicals: one at the local recruitment centre and another, more detailed medical, on arrival at one of the training camps. Camps were set up around the country, the main centre being at Tempe near Bloemfontein. Others included Potchefstroom, Rosebank in Cape Town, Pietermaritzburg, Durban, Booysens in Johannesburg, and Pretoria. Here, men were brought together in their units and equipped before embarking on a ship. Directing men to the various training centres required careful planning as reservations on trains needed to be made and confirmed, meals booked and transport arranged for getting to and from the stations. Communications needed to be made with the receiving destination and finance departments to ensure the recruit was expected and to account for any expenses incurred. ${ }^{75}$ A similar process was followed in getting men embarked for GSWA.

\section{Equipping and moving the forces}

It was one thing getting the men, but they needed equipment, especially as most ordnance in the Union had left with the Imperial garrison. Before the garrison departed, the desperation of the Union's position was set out on 17 August 1914 to the Commander in Chief South Africa and Acting High Commissioner: ${ }^{76}$

Ministers are being pressed to take active steps in German South West Africa, and yet, when they ask for certain equipment from the Imperial stores, they are informed that the only things that can be given them are certain vehicles whose serviceableness is under grave suspicion [... Can we] have issued to us signalling and, especially medical equipment, of which we are very short, and the improvising of which will be a costly and unsatisfactory arrangement. We also require 
ambulances and water carts. ${ }^{77}$

This followed on from a telegram, 12 August, from the Secretary of State for Colonies to the Acting Governor General:

Artillery which your Ministers desire to retain is urgently required at Home in view of impending military operations on a large scale. It is realised by His Majesty's Government that your Government has not yet had the time necessary to organise strong forces of Artillery in the highest state of efficiency, but they feel confident that forces of Union as they stand will prove equal to the task of seizing Colonies of main importance in enemy's territory, and they believe this will probably prove tantamount to conquest of whole. ${ }^{78}$

The Union government was quite aware of its shortages and the unlikelihood of getting anything from London as evidenced by requests to other territories on 10 August. Australia eventually supplied ten million rounds of ammunition, whilst New Zealand had none to spare. ${ }^{79}$ India supplied "a much needed lot of QF gun ammunition [...] for use in the neighbouring German territory". ${ }^{80}$ Two guns were sent from Malta with no personnel. However, by not sending the Royal Garrison Artillery to St Helena, Thompson could supply six officers and 148 other ranks to man these and the other guns which the Imperial Army and Navy had supplied. ${ }^{81}$ Weapons and ammunition were also provided by the Portuguese. ${ }^{82}$ Despite these arrangements, communications continued between South African and London regarding the need for guns and ammunition, even after the expeditionary forces had landed in the German colony.

To add to the complexity and anxieties around obtaining weapons, there were specifications around which ammunition could be used. Shortly after being provided with "flat-nosed revolver bullets (so called Dum-Dum)", the officers of the UDF were informed they had to be withdrawn and replaced by pointed-nosed bullets. The same would have to happen with the ammunition issued to McKenzie's force. ${ }^{83}$ The ammunition supplied by the Portuguese was also found to be faulty, which resulted in Botha asking Collyer to investigate. ${ }^{84}$

The availability of equipment - or lack thereof - was one thing, but it was another when the items were available and not getting through to where they were needed. This resulted in Farrar complaining to Crewe. Rather than, as suggested, appointing a small committee to address the difficulties being encountered with the Defence Department, Smuts preferred to appoint government inspectors and an extra assistant to the Quartermaster General. He, Smuts, would also consult the British government for advice on administering supplies. ${ }^{85}$ This resulted in Skinner's appointment to Botha's staff to sort out the lines of communication. The additional appointment and inspectors had an effect as Botha noted on 27 February 1915 that "off-loading is so much improved and [...] we offloaded and disembarked Brits with his right wing and all their kit in one day, and, imagine it 1440 animals and 500 tons of fodder and food in ten days". This contrasted with the 'bad mess' when he arrived. ${ }^{86}$

Other supply issues concerned uniforms and water. Keene identified "inter alia six different types of headgear, three patterns of bandolier equipment worn in various manners, two patterns of leggings, and pimlico of differing material and cut, worn haphazardly" in a photograph taken of forces in GSWA.$^{87}$ As the commander of the $4^{\text {th }}$ (Umvoti) Mounted Rifles explained, he either had to wait three months for material to come from England to be made into uniforms or delve into the emergency supplies of the Active Citizens' Force. ${ }^{88}$

Most of the South African forces were mounted. Although men supplied their own horses as indicated by Hartigan, the horses needed to be fed and watered, blacksmiths and farriers were required for shoeing and veterinary surgeons for medical treatment. The demands made on the horses meant 
that replacements were regularly required resulting in systems needing to be introduced in the Union to locate, purchase and transport them, and food, to where required on the front.$^{89}$ Other personnel included drivers, leaders for mules and donkeys, and herders of cattle ('food on the hoof'). The use of black, Indian and coloured labour meant that interpreters and men who could oversee labour contingents were required. White men who knew the language and were known to the men and their ways were recruited from administrative roles in black areas to oversee labour. ${ }^{90}$ This, in turn, created other challenges as those who enlisted from the civil service, before Botha's ban, were not to be replaced..$^{91}$ As labour needs increased, so the Union began to draw on others, such as the mines, which made use of short-term contracted labour, to provide labour. Men were recruited on condition that they first served alongside the UDF and then took up their work with the mine. ${ }^{92}$ The mines provided assistance where they could: labour, soldiers and expertise such as that offered by Cullinan and asked for of Farrar, a mine owner.

Farrar was a railway expert whose skills would be invaluable to rebuilding the lines in GSWA to the South African gauge and supporting McKenzie in his drive inland. In addition to the laying of lines in and to the German colony, logistical arrangements needed to be put in place to ensure the smooth transport of supplies and men. This required the appointment of men familiar with signals and communication systems between the stations. ${ }^{93}$ The importance of the railways to the Union's endeavours was demonstrated by the appointment of Sir William Hoy as Director of Military Railways with the rank of colonel. ${ }^{94}$ This ensured military requirements were given priority over domestic demands. This was important for co-ordinating the trains used in the rebellion. Botha's strategy was to rail his troops and horses to where they were needed in an attempt to keep them as fresh as possible. Trains were also used for transporting captured rebels to internment bases. On top of all their military and usual domestic work, the railway staff was also responsible for transporting gifts and comforts collected for the men serving. ${ }^{95}$

Motorised transport was used in both GSWA and South Africa as evidenced by Whittall's Armoured Car Contingent and the No. 2 Special Motor Car Contingent respectively. The latter, organised by the Transvaal Automobile Club and consisting of 110 cars supplied by DH Saker and Company, was instrumental in rounding up Christian de Wet. ${ }^{96}$ Other motorised vehicles, which needed to be sourced, transported and manned, included cranes, trucks for moving cargo, and ambulances. When the motorised vehicles failed to function due to a shortage of petrol or as a result of sand being too soft or affecting the mechanics, horse or wagon was used. ${ }^{97}$

November 1914 saw Major Wallace called from the Western Front to return to England for the purpose of making the necessary arrangements for the formation of a South African aviation corps to assist the Union expeditionary force in the campaign against German South West Africa.

Wallace's account of setting up his aviation corps provides another first-hand account of the challenges faced:

On reporting to the War Office I was informed that everything had been arranged and only organisation was necessary. It was found however that practically nothing had been done and no arrangements whatever made. It was impossible to obtain either machines, transport, tools, material or men from the War Office owing to their requirements and as it seemed doubtful at that time that it would be possible to get the Corps together at all, the remaining South African Officers who were with the Expeditionary Force in Flanders were not recalled. [...] got a contract for 12 [Henri Farman] machines to be delivered at the end of February. ${ }^{98}$ 


\section{Other essential functions}

The Department of Defence also had other matters to deal with and organise.

Medical services were split between the Royal Army Medical Corps (RAMC) linked with the Imperial garrison and the South African Medical Corps (SAMC). When the Imperial garrison left the Union, four of the five RAMC hospitals were closed. This left three military hospitals in the Union: one at the Castle, one in Simon's Town and the RAMC hospital at Wynburg. A limited staff were 'transferred on loan' to the UDF. To complete the complement of staff needed, members of the SAMC were called up under the Defence Act and others recruited. Nurses were supplied by the South African Nursing Service. With the invasion of GSWA, a second general hospital was opened at Maitland in Cape Town. In addition, two ships were equipped: the City of Athens as hospital transport and the Ebani as a hospital ship. ${ }^{99}$ By the end of the GSWA campaign, the Ebani had transported 3206 patients ${ }^{100}$ who were distributed between the hospitals and three convalescent homes in Kalk Bay, Wynburg and Johannesburg.

Important to the moving of men and equipment was communication. For this purpose, the telegram was crucial. The outbreak of war meant that urgent telegrams could be received at any time of day or night resulting in arrangements needing to be made for an all-night service. ${ }^{101}$ On 30 September, the Governor-General approved the formation of "the South African Field Post and Telegraph Corps" which consisted of 500 all ranks split into a signal and postal division. Two days later an order went out that all telegrams which needed to be "enciphered or coded" were to be sent to Mr McNeight who was responsible for the Coding Staff. ${ }^{102}$ There had been instances of codes falling into German hands and secret messages sent on open lines, which compromised shipping lines. ${ }^{103}$ It was recommended that, if possible, typists should also be stenographers to enable them to be as versatile as possible. ${ }^{104}$ In the field -

the method adopted [to send a telegram to GHQ was] to send a telegraphist two miles to the nearest telegraph line twice a day over the most appalling track it is possible to imagine, there he had to climb the telegraph pole and cut into the line. ${ }^{105}$

Censorship was initially managed from Pretoria, but relocated to Cape Town after army headquarters had moved there. ${ }^{106}$ This eased pressure on the Union government which took upon itself to monitor and censor mail passing through Portuguese East Africa as it was known that the neutral territory was being used as a communication channel for the Germans in East Africa. ${ }^{107}$ In addition to the processes the Union had in place, the British government ordered or offered advice. For example, on 17 September 1914 it recommended that the "procedure for dealing with postal matter for or from enemy territory is to accept but not to forward such correspondence. It is opened and letters of no importance are destroyed." 108

Internal security was crucial too, although it took until 12 October to introduce Martial Law. ${ }^{109}$ Steps had however been put in place as noted by Hans Neuhaus, later Henry Newhouse, a Germanborn mining magnate who had become a British citizen in 1907. On 9 September, he noted:

the position of alien enemies, local Germans and Austrians are being treated apparently differently to those at Home. None of them are allowed to leave the Union without a permit and such of them as are Reservists have been arrested and confined in the Agricultural Show Grounds. These men are still being collected from all over South Africa and Rhodesia for this purpose. The others are not being interfered with at all. ${ }^{110}$

The limited police force was further stretched as concerned citizens requested guards over ordnance stores, especially where large numbers of Germans were present or where natives knew the armed forces had been withdrawn. ${ }^{111}$ Other precautions included monitoring Germans handing in 
weapons and moving away from coastal areas. Whilst camps were set up to accommodate those who were felt to be a threat, others were spied on, such as Phillip Pretorius, the South African hunter who lived in German East Africa and who fled to South Africa at the outbreak of war. Pretorius records that De la Rey's sister had been sent by the Union government to spy on him. ${ }^{112}$

In addition to the internment camps, prisoner-of-war camps needed to be organised and managed for those Germans captured in GSWA. Transporting these prisoners required escorts, which depleted the fighting forces back on the front and special arrangements with the railways which transported the men to their destination. ${ }^{113}$ Reports had to be compiled and sent to the Red Cross in line with the Geneva Convention and enquiries into the whereabouts of individuals made when requested. On occasion, this involved investigation into the person's background to determine nationality as Hungarians and Austrians were treated differently compared to Germans. Investigations and motivations were also required to determine whether prisoners were to be exchanged or deported. When German officers were given parole, monitoring their whereabouts needed to be undertaken to ensure adherence. Incarceration of the rebels and arranging legal proceedings against them took up further valuable resources, as did the management of the fines many were required to pay.

\section{Business as usual}

Alongside the arrangements touched on above and others not featured for reasons of space, the South African government still had the usual business of the land to oversee. On 8 September 1914, Parliament met to welcome the Governor-General and to approve South African forces serving outside the Union. A glance at the Hansard Index for the parliamentary session indicates that the war took up a very small part of the proceedings, which lasted three days. The rebellion started the following week as a result of the decisions made and in October, Botha took over as commander-inchief of the UDF, combining this with his role as prime minister. His being in the field meant much of his political work fell onto the shoulders of Smuts.

The biggest issue was finance as it was one area where the political opposition could challenge the government without being accused of treason. Budgets and costs had to be monitored to ensure no excessive spending, and equipment - military, medical and commercial - had to be sourced, if not from within the Union, then from outside. The demands of the war in Europe often meant that the Union had to find alternative markets or products. In addition, enquiries were made and steps put in place to prevent extortion through price-fixing. ${ }^{114}$ Some of these functions fell into the remit of existing departments, such as finance and trade; however, the exigencies of war resulted in additional staff being needed, or work being added to already overstretched officials. Any additional finance expenditure had to be approved by parliament, which invariably led to objections by the Nationalists who felt the local economy should receive preference. As a result, where possible, Buxton would approach the Imperial government for funding to help reduce political pressure on Smuts and Botha who had to present and defend the case in the House of Assembly. ${ }^{115}$

Pressure came from outside the House too. Concerned family members wanted to know the whereabouts of 1500 coloured citizens working in German territory. ${ }^{116}$ On their return to the Union, government had to consider whether to accept the German bank notes these men had been given as there was no guarantee that the Union would be reimbursed for honouring the value of the money. ${ }^{117}$ Offers of service provision also had to be considered by the quartermaster general's office. These included offers to run canteens and to supply water or carrier pigeons. Others wrote in with inventions they had created or had heard about, such as balloons, in the hope that it would assist the armed forces whilst earning them some income. ${ }^{118}$ 
The pressure of the previous four and a half months was telling when, on 19 December 1914, uncharacteristically, Smuts wrote to JX Merriman, senior statesman, "I have never posed as a financial expert and as you know I am half dead with my efforts in quite another direction so you must be good and help." ${ }^{119}$ Following prompts by Buxton and consultations with Botha, David Graaff joined the cabinet on 24 February 1915, having been brought back from London for reasons of health. He became Minister of Finance, technically relieving Smuts and Merriman of the task. ${ }^{120}$

\section{Conclusion}

By February 1915, the situation in South Africa caused by Britain's declaration of war on Germany had calmed enough for Smuts to join Botha in GSWA from April 1915 indicating that by then, the defence department was sufficiently organised to look after itself. The rebellion had been brought to a close by early December 1914 and at the end of the month, the campaign against GSWA was effectively relaunched. With Botha in the driving seat, the GSWA campaign was brought to an end on 9 July 1915. This did not stop the Nationalists in their objection to the war, and their outcries were to influence the demobilisation plans and subsequent recruitment for service in Europe, East Africa and other theatres. ${ }^{121}$

Despite the hurdles the Nationalists and others put in the way, the transformation the UDF had undergone was evident in the organisation of the forces eventually sent to East Africa in 1916 and to Europe by late 1915. Most noticeably, the commando system was done away with, although units, which had fought in GSWA, were generally kept together in the East Africa brigade. Although there were still errors caused by inexperience, such as the calculation of reinforcements being ignored, the compilation and processing of recruiting men for service after GSWA were more structured and documented than at the start of the war. The Union still had lessons to learn in terms of supplying the troops and dealing with variable terrain, but given its starting point, it had come a long way.

$1 \quad$ I Uys. Roll call: The Delville Wood story. Johannesburg: Uys Publications, 1991; B Nasson. Springboks on the Somme: The People's War. Johannesburg: Penguin, 2007; T Couzens. The great silence: From Mushroom Valley to Delville Wood: South African Forces in World War I. Johannesburg: Sunday Times Books, 2014.

E Paice. Tip and run: The untold tragedy of the Great War in Africa. London: Weidenfeld \& Nicolson, 2007; R Anderson. The forgotten front. Stroud: Tempus, 2007; H Strachan. The First World War in Africa. Oxford: Oxford University Press; A. Samson. Britain, South Africa and the East Africa Campaign, 1914-1918: The Union comes of age. London: IB Tauris, 2006; A Samson. World War 1 in Africa: The forgotten conflict of the European powers. London: IB Tauris, 2013.

J Stejskal. The horns of the beast: The Swakop River Campaign and World War I in South-West-Africa, 1914-1915. Solihul: Helion; G McGregor The World War 1 in Namibia. Windhoek: Gondwana Collection, 2014; A Cruise. Louis Botha's war: The campaign in South West Africa, 1914-1915. Cape Town: Zebra, 2015. Home front histories can be found in V Bickford-Smith, E van Heyningen \& N Worden. Cape Town in the twentieth century. Claremont: D Philip, 1999; PS Thompson. "The Natal Homefront in the Great War (1914-1918)". Historia 56/1. 2011; B Nasson. World War I and the people of South Africa. Cape Town: Tafelberg, 2014; A Grundlingh \& S Swart. Radelose rebellie? Dinamika van die 1914-1915 Afrikanerrebellie. Pretoria: Protea, 2009. Although in a civilian position, Bourne had seen military action during the 1899-1902 war in southern Africa with The Royal Scots (Lothian Regiment). A Seegers. The Military and the making of modern South Africa. London: IB Tauris, 1996, 22, 25. The figure includes 1693 positions that were vacant. Seegers op. cit., p. 25.

Ibid., p. 25.

J Wolfe Murray on the outbreak of war and from October 1914 Charles Thompson.

R Geyer. "Die eerste operasionele optrede van die univerdedigingsmag - Januarie 1914". Unpublished 
MA thesis, University of Pretoria, Pretoria, 2009.

Seegers op. cit., p. 40.

Ibid., p. 22.

Ibid., p. 29; Department of Defence (DOD): AG 1914-1921 152, Mobilisation of units, Communications 17-21 September 1914.

Union of South Africa Act 1909 <https://media.law.wisc.edu/s/c_8/jzhy2/cbsa1.pdf> Accessed 17 November 2015.

Ibid.

A Samson, Britain, South Africa ... op. cit.

The governor-general was also the high commissioner of South Africa. As high commissioner he was responsible for the protectorates of Bechuanaland, Basothuland and Swaziland. He was also responsible for the British South Africa Company territories of Northern and Southern Rhodesia. The focus in this paper is on the governor-general as the King's representative in South Africa. S Buxton. General Botha. London: John Murray, 1924, 40; According to the family tree (http://histfam.familysearch.org/getperson.php?personID=I69414\&tree=Nixon), De Villiers died on 2 September and was buried on 7 September 1914. Accessed on 2 March 2014. The National Archives, London (hereafter TNA): ADM 137/9, Telegram Secretary of State for Colonies (SoSC) to Acting Governor-General (GG), 6 August 1914.

South African National Archives, Pretoria (hereafter SANA): PM 1/1/12 4/37/14, Minute 9/15, 7 August 1914; Samson, World War 1 in Africa ... op. cit., p. 69.

WM Bisset. "A short history of Fort Wynyard, Table Bay defences". Scientia Militaria 9/4. 1979. 4954 .

The National Archives, London (TNA): WO 32/5026.

Union Defence Act, 1912.

Although it has not been stated in any document located to date, the South African government may well have been responding to the general perception that the war was going to be over by Christmas 1914.

I van der Waag. "The battle of Sandfontein, 26 September 1914: South African military reform and the German South-West Africa campaign, 1914-1915”. First World War Studies 4/2. 2013. 141-166; N Helme. Thomas Major Cullinan: A biography. Johannesburg: McGraw-Hill, 1974, 105.

Bodleian Library, Oxford: MSS Afr s. 2175 George Farrar Box 12/1, letter 20 September 1914.

Thompson op. cit., pp. 101-137; AC Martin. Durban Light Infantry 1854-1934, Vol. 1. Durban: Headquarter Board of Durban Light Infantry, 1969.

Martin op. cit., p. 149; DOD: AG 1914-1921 152, Strengthening of defensive armament, Coast, Durban.

Anderson op. cit.; Paice op. cit.

SANA: PM 1/1/32, Telegrams Senior Naval Officer (SNO) Simon's Town to GG, 20 August 1914 \& 18 September 1914.

TNA: CO 616/30-CO 616/39; SANA: GG 693 9/93/133, Telegram SoSC to GG, 7 November 1914.

Martin op. cit.

SANA: PM 1/1/32 op. cit. Various telegrams Naval CiC and GG; Samson, World War 1 in Africa ... op. cit., p. 65; A. Samson. "South Africa mining magnates and World War One". Academia.Edu. $<$ https://www.academia.edu/1754155/South_African_Mining_Magnates_and_World_War_One $>$

Accessed on 1 March 2014.

SANA: PM 1/1/32 op. cit. Minute 759, 17 August 1914.

Samson, Britain, South Africa ... op. cit. Manie Maritz was accused of withholding information of the German incursion while in parliament; Smuts was accused of manipulating the map to prove the Germans had been in South African territory.

Ibid.

TNA: ADM 137/9, Telegram Naval Commander in Chief (CiC) Cape to Admiralty, 31 August 1914. A Samson. "South Africa and the First World War". In TRE Paddock (ed.), World War 1 and propaganda. Leiden: Brill, 2014.

HF Trew. Botha treks. London: Blackie, 1937, 9.

DOD: AG 1914-1921 152, Mobilisation of units, Communications regarding President Steyn Brits Defence Rifle Association, 18 \& 30 October 1914.

Martin op. cit., p. 150.

Brenthurst Library: MS034 AE Lorch, A story of the Cape Mounted Riflemen; TNA: ADM 137/9

Officer administering Union of South Africa to SoSC, 17 August 1914; Defence HQ, The Union of 
South Africa and the Great War 1914-18: Official history, 13.

J Ploeger. "The skirmish at Grassplatz". Scientia Militaria 4/1. 1974.

Ian van der Waag op.cit; J. Ploeger. "The action at Sandfontein". Scientia Militaria 4/1. 1974.

SANA: PM 1/1/32 op. cit. Telegrams between Naval CiC and GG, 27-28 September 1914 \& 2 October 1914; GG 673 9/93/133, Telegram 17 October 1914.

J Ploeger, "The skirmish at Grassplatz", in Scientia Militaria, vol 4 no 1, 1974.

SANA: PM 1/1/32 op. cit. Botha minute 994, 8 October 1914.

Ibid. Telegram Naval CiC to GG, 9 October 1914; TNA: ADM 137/9, Telegram Naval CiC to Admiralty, 18 August 1914. Lambert was appointed the transport officer for the Union on 20 August 1914.

Trew op. cit.

The 1st Rhodesian Regiment was eventually sent to South Africa in November as a result of Buxton's involvement. TNA: ADM 137/9, various communications, esp. telegrams High Commissioner South Africa to SoSC, 16 \& 23 September 1914 re Rhodesians.

TNA: CO 551/62 4765930 Nov 1914 telegram.

G Wills, Letter "My dear mother", 14 August 1914. John Wills. 2005. <http://www.oceanharmony.ca/1914\%20letters.html> Accessed on 24 February 2014.

TNA: ADM 139/7, handwritten note signed Harcourt, 8 August 1914.

WK Hancock \& J van der Poel (eds). Selections from the Smuts papers: June 1910-November 1918, Vol. III. Cambridge: Cambridge University Press, 1966, 186-187.

Ibid., p. 187.

Ibid., p. 188.

William Cullen Library, University of the Witwatersrand Archive (hereafter Wits): Crewe papers, Smuts to Crewe, 21 August 1914.

Hancock \& Van der Poel op. cit., p. 198; Western Cape Archive (KAB): 1/AXA 7/1, Telegram A1591 Minister of Justice, 22 September 1914.

KAB: 1/AXA 7/1, Letter LH Fowler, 25 August 1914.

Helme op. cit.

KAB: 1/AXA 7/1, Letter LH Fowler, 25 August 1914; 3/KWT 4/1/242, Letter Magistrate to Mayor of King William's Town, 27 August 1914; DOD: AG 1914-1921 152.

Samson, World War 1 in Africa ... op. cit.

Van der Waag, op. cit., pp. 141-166.

Brenthurst: MS035 Hartigan's diary, pp. 355-356.

KAB: 3/CT 4/1/2/92 letters dated 24 and 16 August, 1 and 5 September 1914 between E Beardmore and John Parker, Mayor of Cape Town, telegram D9199 from Defence to Mayor, 25 August 1914.

SANA: PM 1/1/32 Supply of ammunition and guns, Urgent telegram GG to SoSC, 19 September 1914; KAB: 3/CT 4/1/2/92, G95/2 letter from J Wolfe Murray to John Parker, Mayor of Cape Town re Imperial Army no longer recruiting in South Africa, 14 September 1914 and newspaper article signed by Fitzpatrick and Byron, 16 September 1914.

KAB: 3/CT 4/1/2/92, file 95/2, Letter Smuts to Parker, 12 September 1914.

Percival Frere Smith [b. 8 Sep 1877 in West Hill, Grahamstown; d. Jan 1960 in Sutton Valence, Kent] $<$ http://archiver.rootsweb.ancestry.com/th/read/SOUTH-AFRICA-IMMIGRANTS-BRITISH/200803/1206485603> Accessed on 28 November 2015.

National Army Museum, London: 9402-01, People's Legion, Cape Times cutting 7 October 1914.

DC Jacobs. Kya Rosa: Home of Alumni. University of Pretoria. 2011. $<$ http://web.up.ac.za/default.asp?ipkCategoryID=1514> Accessed on 28 February 2014.

KAB: 1/AXA 7/1, Telegram A1599 Minister of Justice, 25 September 1914.

Brenthurst: MS035 Hartigan's diary, pp. 389-393.

By early 1915, Union troops were serving in GSWA, Nyasaland and with the 2nd Rhodesian Regiment in East Africa.

DOD: DC $631 \mathrm{Gp} 2$.

Hancock has the recipient of this letter as General AJ Murray. This is not possible, as AJ Murray was serving on the Western Front, while J Wolfe Murray was in South Africa before he became Chief of the Imperial General Staff on his return to Britain in October 1914. See "The Great War Timeline 1914". $<$ http://www.greatwar.co.uk/timeline/ww1-events-1914.htm> Accessed on 28 February 2014. Pending Buxton's arrival, his dual role was split between Sir De Villiers as acting governor-general and Wolfe Murray as acting high commissioner.

Hancock \& Van der Poel op. cit., p. 189.

SANA: PM 1/1/32 op. cit. Telegram SoSC to Acting GG, 12 August 1914. 
Ibid.; various telegrams.

Hancock \& Van der Poel op. cit. letter dated 21 August 1914. p. 190; SANA: PM 1/1/32 op. cit. Telegram SNO Simonstown to GG, 6 October 1914.

Ibid.; Thompson to GG, 29 September 1914.

JL Keene. "The problem of munitions supply in the First World War and its effect on the Union Defence Force". South African Military History Journal 6/4. 1984. <http://samilitaryhistory.org/vol064jk.html> Accessed on 28 February 2014; Samson, World War 1 in Africa ... op. cit.; Samson, Britain, South Africa ... op.cit.

SANA: PM 1/1/32 op. cit. Letter from Thompson to GG, 28 September 1914.

Hancock \& Van der Poel op. cit. pp. 237-238.

University of Witwatersrand Archive (Wits): Crewe papers, Letters 8 \& 16 November 1914.

Hancock and Van der Poel op. cit., p. 242.

Keene op. cit.

DOD: AG 1914-1921 152, Mobilisation of units, Letter S Carter to District Staff Officer, Pietermaritzburg, 4 September 1914.

DOD: DC 631 Gp 2, Veterinary Services UDF.

KAB: 1/ELN 70 90/14, Recruitment requests, 1 \& 20 October 1914.

KAB: 1/AXA 7/1, Telegram S565, 8 September 1914.

SE Katzenellenbogen. South Africa and southern Mozambique: Labour, railways and trade in the making of a relationship. Manchester: Manchester University Press, 1982.

A breakdown in signalling and communications led to Farrar's death, 20 May 1915; Samson. World War 1 in Africa ... op. cit.; An accident at Hex River Pass, 11 September 1914, saw 10 soldiers die and 103 seriously injured.

G Miescher. "Arteries of empire: On the geographical imagination of South Africa's Railway War, 1914/5". Kronos 38/1. 2012. <http://www.scielo.org.za/scielo.php?pid=S025901902012000100003\&script=sci_arttext> Accessed on 1 March 2014.

KAB: 1/AXA 7/1 Letter from Quartermaster General, 21 September 1914.

SA Brigade. "A driver mechanic and his role in the capture of General De Wet in 1914". Gentleman's Military Interest Club. 2010. <http://gmic.co.uk/index.php?showtopic=45663> Accessed on 1 March 2014.

Helme op. cit.; R Murray. The ear diaries of Dr Charles Molteno 'Kenah' Murray, Book 2: The invasion of German South West Africa February-August 1915. 2013. $<$ http://www.moltenofamily.net/wp-content/uploads/2013/12/The-Invasion-of-German-South-WestAfrica-pdf.pdf $>$ Accessed on 1 March 2014.

TNA: AIR 1/1247/204/7/1, Report by Major Wallace on formation of South African Aviation Corps for service in South West Africa.

WG Macpherson. Medical services, general history: Medical services in the United Kingdom, in British Garrisons overseas, and during operations against Tsingtau, Togoland, the Cameroons and South West Africa. London: HMSO, 1921, 310-313; KAB: 1/AXA 7/1 Letter Acting Staff Officer, No 3 Military District, 26 January 1915.

KAB: 1/AXA 7/7 file 140/50, 2 September 1915.

DOD: AG 1914-1921 152, Mobilisation of units, 24 August 1914.

Ibid. Memorandum to Director of Supplies, Transport, Ordnance Stores and Pay, 2 October 1914.

TNA: ADM 137/9.

DOD: AG 1914-1921 152, Mobilisation of units, Telegram to Censor, 23 September 1914.

TNA: AIR 1/1247/204/7/1 Report by Major Wallace, p. 7.

TNA: ADM 137/9, Telegram GG to SoSC, various communications between 21 and 30 September 1914.

Samson, World War 1 in Africa ... op. cit.; CO 616/35-CO 616/39 various files.

DOD: AG 1914-1921 152, Mobilisation of forces, Telegram SoSC to GG, 17 September 1914.

SANA: GG 673 9/9/133, Telegram General Officer Commanding South Africa to GG, 16 October 1914.

JDF Jones. Through rock and fortress: The story of Gencor 1895-1995. Cape Town: Jonathan Ball, $1995,69$.

DOD: AG 1914-1921 152, Mobilisation of units, communications regarding King William's Town, 1 September 1914.

PJ Pretorius. Jungle man. London: Harold Wimbury, 1947.

DOD: AG 1914-1921 152, Mobilisation of units, Report to Staff Officer, 27 August 1914.

KAB: 1/ELN 70 19/14, Letter from Magistrate, 19 August 1914; 3/CT 4/1/2/92, file G91/2. 
117

118

119

120

121

Samson. Britain, South Africa ... op. cit.

KAB: 3/CT 4/1/2/92, file G93/2, Telegrams Mayor and Minister of Interior, 17 \& 18 August 1914.

Ibid., various communications; SANA: GG 673 9/93/133, Telegram American Consul General Cape Town to GG, 22 September 1914.

DOD: DC 631 A Gp 2, file A 220/9199 QMG, Field canteens; DC 621 Gp 2, file Water supplies; AG 1914-1921 152, telegram to Pietermaritzburg, 28 September 1914.

Hancock and Van der Poel op. cit., p. 221.

Ibid., pp. 241-242.

See Samson. Britain, South Africa... op. cit. for details. 